\title{
Teaching NeuroImages: Cerebrotendinous xanthomatosis
}

\section{A rare treatable adult-onset lipid storage disease}

Mina S. Makary, MD, Yaz Y. Kisanuki, MD, Nessim N. Amin, MD, and Hasel W. Slone, MD

Neurology ${ }^{\circledR}$ 2018;90:e637-e638. doi:10.1212/WNL.0000000000004967

Correspondence

Dr. Makary

mina.makary@osumc.edu

Figure Brain MRI and spectroscopy demonstrate characteristic findings of cerebrotendinous xanthomatosis
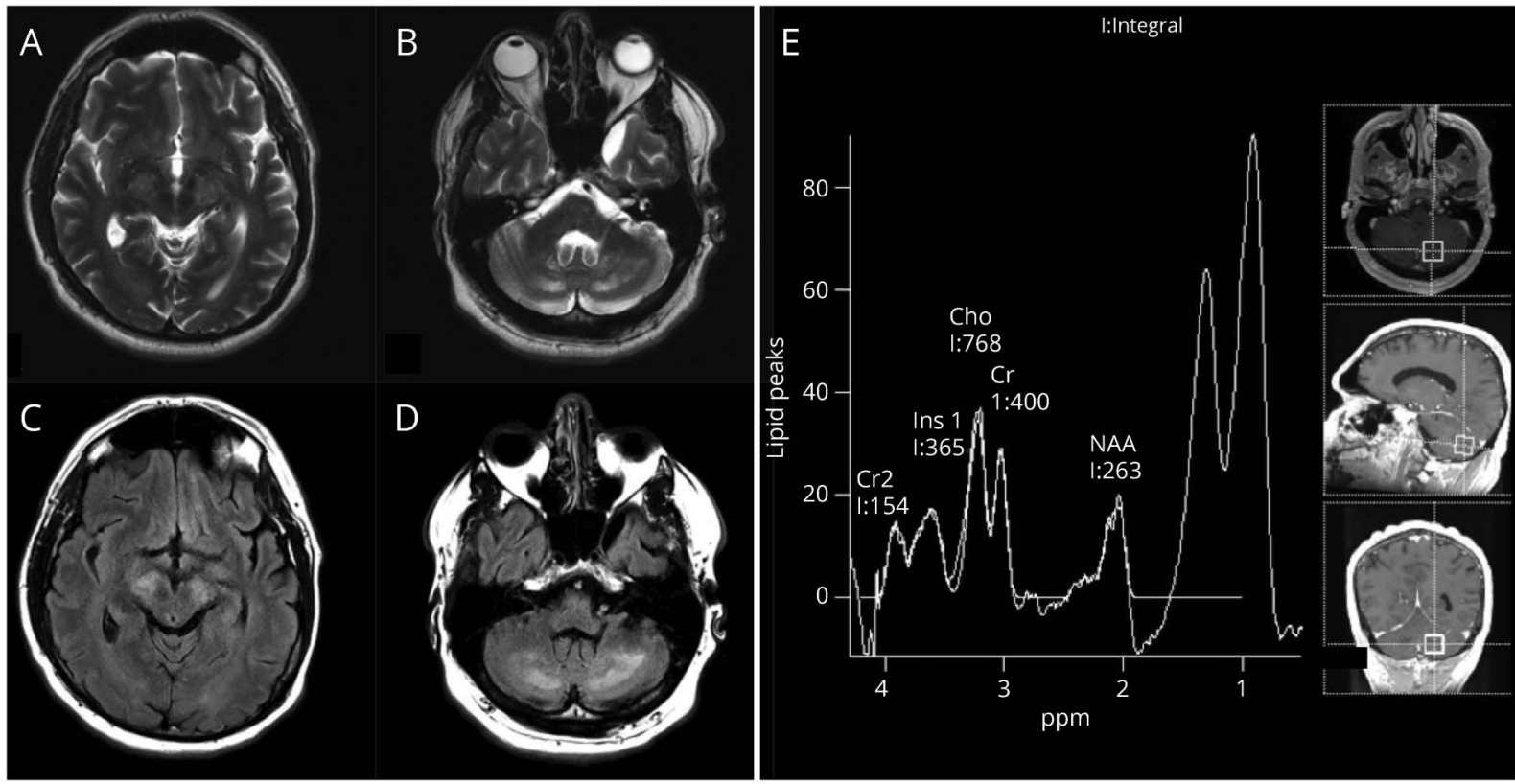

(A, B) Axial T2-weighted and (C, D) fluid-attenuated inversion recovery images demonstrate T2 hyperintensities involving the thalami, midbrain, dentate nuclei, and deep cerebellar white matter. (E) Magnetic resonance spectroscopy reveals typical lipid peaks at 0.9 and $1.3 \mathrm{ppm}$. Cho $=\mathrm{choline} ; \mathrm{Cr}=\mathrm{creatine}$; $\mathrm{NAA}$ $=N$-acetylaspartate.

A 39-year-old previously healthy man presented with insidiously progressive paresthesia in his lower extremities and worsening of gait and balance. MRI demonstrated T2-hyperintense signal abnormalities involving the thalami, midbrain, dentate nuclei, and adjacent deep cerebellar white matter, which are characteristic of cerebrotendinous xanthomatosis (CTX) (figure). Magnetic resonance spectroscopy revealed typical lipid peaks at 0.9 and $1.3 \mathrm{ppm},{ }^{1}$ and serology analysis indicated sterol 27 -hydroxylase deficiency, ${ }^{2}$ confirming the diagnosis. CTX is a rare lipid storage disease with unique clinical and imaging findings, and effective treatment with positive outcomes if initiated early, raising the importance of awareness and early recognition of this disease. ${ }^{2}$

\section{MORE ONLINE}

\section{$\rightarrow$ Teaching slides:}

links.lww.com/WNL/A244

From the Division of Neuroradiology, Department of Radiology (M.S.M., H.W.S.), and Department of Neurology (Y.Y.K., N.N.A.), The Ohio State University Wexner Medical Center, Columbus.

Go to Neurology.org/N for full disclosures. Funding information and disclosures deemed relevant by the authors, if any, are provided at the end of the article. 


\section{Author contributions}

Mina S. Makary: study concept, analysis of MRI data, drafting and revising the manuscript, final approval. Yaz Y. Kisanuki, Nessim N. Amin: study concept, revising the manuscript, final approval. Hasel W. Slone: study concept, study supervision, analysis of MRI data, revising the manuscript, final approval.

\section{Study funding}

No targeted funding reported.

\section{Disclosure}

The authors report no disclosures relevant to the manuscript. Go to Neurology.org/ $\mathrm{N}$ for full disclosures.

\section{References}

1. Embiruçu E, Otaduy M, Taneja A, et al. MR spectroscopy detects lipid peaks in cerebrotendinous xanthomatosis. AJNR 2010;31:1347-1349.

2. Nie $S$, Chen G, Cao X, et al. Cerebrotendinous xanthomatosis: a comprehensive review of pathogenesis, clinical manifestations, diagnosis, and management. Orphanet J Rare Dis 2014;9:179-190. 


\section{Neurology}

\section{Teaching NeuroImages: Cerebrotendinous xanthomatosis: A rare treatable adult-onset lipid storage disease}

Mina S. Makary, Yaz Y. Kisanuki, Nessim N. Amin, et al.

Neurology 2018;90;e637-e638

DOI 10.1212/WNL.0000000000004967

This information is current as of February 12, 2018

Updated Information \&

Services

References

Subspecialty Collections

Permissions \& Licensing

Reprints including high resolution figures, can be found at: http://n.neurology.org/content/90/7/e637.full

This article cites 2 articles, 1 of which you can access for free at: http://n.neurology.org/content/90/7/e637.full\#ref-list-1

This article, along with others on similar topics, appears in the following collection(s):

All Clinical Neurology

http://n.neurology.org/cgi/collection/all_clinical_neurology

Leukodystrophies

http://n.neurology.org/cgi/collection/leukodystrophies

Lipidoses

http://n.neurology.org/cgi/collection/lipidoses

MRI

http://n.neurology.org/cgi/collection/mri

Information about reproducing this article in parts (figures,tables) or in its entirety can be found online at:

http://www.neurology.org/about/about_the_journal\#permissions

Information about ordering reprints can be found online:

http://n.neurology.org/subscribers/advertise

Neurology ${ }^{\circledR}$ is the official journal of the American Academy of Neurology. Published continuously since 1951, it is now a weekly with 48 issues per year. Copyright (O 2018 American Academy of Neurology. All rights reserved. Print ISSN: 0028-3878. Online ISSN: 1526-632X.

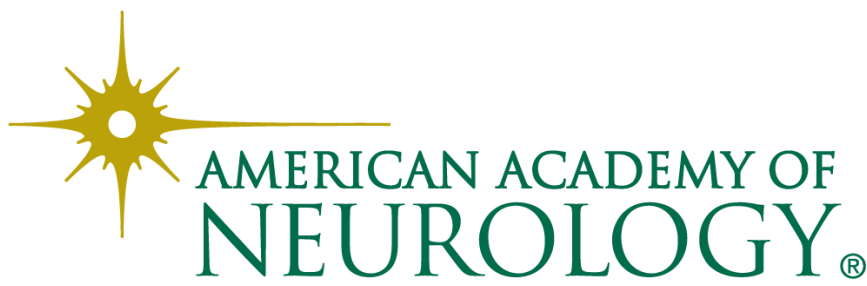

